\title{
Zastosowanie reguł konwersacyjnych Paula Grice'a w komunikowaniu politycznym - analiza porównawcza exposé Donalda Tuska i Beaty Szydło
}

Istnieje wiele sposobów określania tego, co jest istotą komunikowania politycznego. Jednak próba precyzyjnego sformułowania jednej tylko właściwej definicji napotyka na trudności ze względu na niejednoznaczność rozumienia pojęć „komunikowanie” i ,polityka”.

Wybitna polska politolog, specjalizująca się w dziedzinie nauk o komunikowaniu, Bogusława Dobek-Ostrowska, definiuje komunikowanie polityczne jako celowe komunikowanie o polityce ${ }^{2}$. Z perspektywy teoretycznej komunikowanie polityczne ma na celu wyjaśnienie i zrozumienie procesów politycznych i komunikacyjnych $^{3}$. Z kolei Dorota Piontek podkreśla, że system komunikowania politycznego stanowi strukturę złożoną z elementów należących do systemu polityki i sfery publicznej w aspekcie mediów masowych ${ }^{4}$. Komunikowanie polityczne może być również określone jako swoisty regulator komunikacji pomiędzy politykami i mediami ${ }^{5}$. Zdaniem francuskiego medioznawcy Dominique'a Woltona komunikowanie polityczne jest przestrzenią, w której ma miejsce dyskurs pomiędzy politykami, dziennikarzami i opinią publiczną, mającymi legitymizację do wyrażania publicznie swoich sądów i opinii w sprawach polityki ${ }^{6}$. Z kolei brytyjski badacz

\footnotetext{
* Dr, e-mail: rafalles@vp.pl; Instytut Edukacji Medialnej i Dziennikarstwa Uniwersytetu Kardynała Stefana Wyszyńskiego w Warszawie, ul. Dewajtis 5, 01-815 Warszawa.

${ }^{1}$ Por. B. McNair, An introduction to political communication, Routledge, Londyn-Nowy Jork 2011, p. 3.

${ }^{2}$ Por. B. Dobek-Ostrowska, Komunikowanie polityczne i publiczne, Wydawnictwo Naukowe PWN, Warszawa 2012, s. 130.

${ }^{3}$ Por. tamże, s. 131.

${ }^{4}$ Por. D. Piontek, Komunikowanie polityczne i kultura popularna. Tabloidyzacja informacji o polityce, Wydawnictwo Naukowe WNPiD UAM, Poznań 2011, s. 14.

${ }^{5}$ Por. tamże.

${ }^{6}$ Por. D. Wolton, La communication politique: construction d'un modèle, „Hermès” (Une revue de l'Institut des sciences de la communication du CNRS) 1989, n. 4, s. 27-32, 35, http://documents.irevues.inist.fr/handle/2042/15353 [dostęp: 01.08.2016], http://documents.irevues.inist.
} 
mediów i procesów komunikowania Brian McNair definiuje komunikowanie polityczne jako celowe komunikowanie dotyczące polityki, w którym uczestniczą organizacje polityczne, media oraz obywatele ${ }^{7}$.

\section{Exposé - formą komunikowania politycznego. Analiza dyskursu politycznego i teoria implikatur konwersacyjnych Paula Grice'a}

Exposé jest formą komunikowania politycznego - oznacza przemówienie programowe nowo desygnowanego prezesa Rady Ministrów na forum parlamentu. Ten rodzaj dyskursu angażuje środowisko polityków, dziennikarzy, mass media i opinię publiczną, tym samym spełnia kryteria zaproponowanych wyżej różnych ujęć definicyjnych tego, co stanowi istotę komunikowania politycznego.

Analiza dyskursu politycznego może przebiegać kilkoma drogami. Pierwsza z nich polega na analizie treści komunikatu, czyli analizie tego, co explicite jest w nim zawarte, co jest wyrażone w sposób wyraźny, jasny, sprecyzowany. Zasadniczo odbiorca komunikatu nie ma wątpliwości, co do jakości intencji przekazującego komunikat, ponieważ nadawca wyraża jednoznacznie treść komunikatu. Drugi z możliwych sposobów analizy dyskursu politycznego to odkrywanie założeń ukrytych na drodze presupozycjonalnej, zawierającej niewyartykułowane stwierdzenia, które leżą u podstaw deklarowanego oglądu rzeczywistości politycznej. W przekonaniu autora należałoby wskazać jeszcze trzecią drogę analizy, która uzupełnia powyższe sposoby analizy dyskursu politycznego. Polega ona na odwołaniu się do tzw. zasady współpracy, zakładającej, że uczestnicy procesu komunikowania przestrzegają zestawu racjonalnych, uniwersalnych reguł, nieartykułowanych wprost, ale oczywistych dla komunikujących się osób. W tym miejscu autor odnosi się do teorii komunikacji Paula Grice'a. Wspomniane wyżej reguły to reguła jakości, ilości, istotności oraz sposobu, które organizują komunikowanie się i gwarantują jego skuteczność. Reguły te odnoszą się do tego, co zostało wypowiedziane explicite i implicite. Tym samym umożliwiają analizę informacji zawartej w dosłownej formie komunikatu i tej niewyartykułowanej. W przypadku świadomego, intencjonalnego nieprzestrzegania reguł konwersacji należałoby dokonać próby wskazania aluzyjnego znaczenia komunikatu, czyli wskazania implikatur konwersacyjnych wypowiedzi. Implikatura, choć nie jest zawarta w dosłownej treści przekazu, to jednak istnieje i spełnia właściwe sobie funkcje, a odbiorca ma tego świadomość.

fr/bitstream/handle/2042/15353/HERMES_1989_4_27.pdf?sequence=1\&isAllowed=y [dostęp: 1.08.2016].

${ }^{7}$ Por. B. McNair, dz. cyt., s. 6; D. Piontek, dz. cyt., s. 15. 
Autor podejmie próbę odniesienia treści semantycznych zawartych w poddanych analizie exposé do reguł Grice'a dla zweryfikowania stopnia zastosowania teorii implikatur konwersacyjnych Grice’a w przemówieniach programowych Donalda Tuska i Beaty Szydło. Skonfrontowane zostaną także treści o charakterze niesemantycznym obecne $\mathrm{w}$ analizowanych dyskursach politycznych $\mathrm{z}$ wymienioną teorią.

Zgodnie z proponowaną definicją Stownika języka polskiego PWN termin „semantyka” w odniesieniu do procesów komunikowania wskazuje na związek, jaki zachodzi między wyrażeniami języka a przedmiotami, do których się odnosi. W drugim znaczeniu „semantyka” oznacza dział językoznawstwa, którego przedmiotem jest analiza znaczeń wyrazów ${ }^{8}$. Semantycznie określone warunki prawdziwości podkreślają zatem realne, weryfikowalne explicite, zbadanie konkretnej sytuacji komunikacyjnej. Z kolei pragmatycznie określona implikatura zależna jest od kontekstu sytuacyjnego dyskursu, jest odwoływalna, wywnioskowana, a nie odkodowana z jego treści. W niniejszych badaniach autor weźmie pod uwagę dwa aspekty komunikowania politycznego: semantyczny i niesemantyczny, odnosząc je do reguł Grice’a. Należy podkreślić, że teoria reguł konwersacji w ujęciu Grice’a jest zasadniczo zaliczana do ogólnej teorii pragmatyki języka, choć nosi ona również cechy dotyczące semantyki przekazu'. Przedmiotem pragmatyki są ,społeczne i sytuacyjne warunki funkcjonowania języka oraz cele, jakie mówiący chce osiągnąć przez użycie określonych wyrazów i wyrażeń"

Zdaniem Grice'a komunikowanie powinno być pojmowane jako zachowanie celowe; status nadrzędny ma w nim zasada kooperacji rozumiana jako dążenie komunikujących się partnerów do osiągnięcia wcześniej zaplanowanego celu. Akty komunikowania mają jednak swoje odniesienie do semantyki języka. Nadawca i odbiorca komunikatu posiadają w jakiejś przynajmniej mierze wspólny system semantyczny. Z socjologicznego punktu widzenia można mówić o tzw. typizacji doświadczeń poszczególnych osób, to z kolei prowadzi do wypracowania podobnych językowych form komunikacyjnych, w konsekwencji możliwa staje się ich spójna interpretacja warunkująca porozumienie i współdziałanie ${ }^{11}$. Przedmiotem badań będą zarówno elementy semantyki, jak i pragmatyki exposé dla zrozumienia intencji, z jakimi nadawca wysłał komunikat.

\footnotetext{
${ }^{8}$ Por. Semantyka [hasło], [w:] Stownik języka polskiego, http://sjp.pwn.pl/sjp/semantyka;2575165 [dostęp: 1.08.2016].

${ }^{9}$ Por. A. Kiklewicz, Reguty konwersacji H.P. Grice'a. Pragmatyka czy semantyka?, „Linguistica Copernicana" 2011, nr 2 (6), s. 29, http://www.linguistica.umk.pl/teksty/06_kiklewiczzn.pdf [dostęp: 01.08.2016].

${ }^{10}$ Pragmatyka [hasło], [w:] Stownik języka polskiego, http:/sjp.pwn.pl/sjp/pragmatyka;2572266.html [dostęp: 1.08.2016].

${ }^{11}$ Por. A. Kiklewicz, dz. cyt., s. 30.
} 


\section{Metodologia badań}

Celem badań jest określenie, w jakim stopniu Donald Tusk i Beata Szydło wykorzystują w swoich exposé cztery podstawowe reguły Grice’a, a także wskazanie, które z reguł (jakości, ilości, istotności, sposobu) są przez polityków przestrzegane, a które łamane. W przypadku świadomego, intencjonalnego nieprzestrzegania reguł konwersacji, autor dokona próby wskazania aluzyjnego znaczenia wypowiedzi, czyli wskazania implikatur konwersacyjnych wypowiedzi.

Cel badań można sprowadzić do następujących pytań badawczych:

- Czy w exposé prezesów Rady Ministrów z 18 listopada 2011 roku oraz z 18 listopada 2015 roku można zauważyć zastosowanie reguł Grice’a?

- Czy w tych formach komunikacji politycznej można również wyróżnić implikatury konwersacyjne? Jaką pełnią funkcję? Jakie ujawniają intencje nadającego komunikat?

- Jakie są podobieństwa i różnice exposé Tuska i Szydło w odniesieniu do teorii implikatur konwersacyjnych Grice'a?

Wśród hipotez badawczych można wskazać następujące:

- W exposé Donalda Tuska i Beaty Szydło spełnione są wszystkie reguły Paula Grice’a lub też w exposé Tuska i Szydło spełnione są tylko niektóre reguły Grice’a albo też żadna z tych reguł nie jest spełniona.

- W dyskursie Tuska i Szydło można zauważyć obecność implikatur konwersacyjnych albo w dyskursie Tuska i Szydło nie zauważa się obecności implikatur konwersacyjnych.

- W odniesieniu do teorii implikatur konwersacyjnych w przemówieniach programowych Tuska i Szydło istnieją lub też nie istnieją podobieństwa i różnice.

Jeśli chodzi o metodę badań, autor posługuje się krytyczną analizą dyskursu w rozumieniu Habermasa i Foucaulta. Szczególna uwaga zostaje zatem skierowana na konsekwencje komunikowania, zastosowanych praktyk językowych, na zmiany społeczne. W podjętej analizie dyskurs rozumiany jest nie tylko w kategorii wymiany komunikacyjnej, ale jako złożona całość, w której język związany jest z ideologią, wiedzą, strategiami społecznymi i komunikacyjnymi. Ścieranie się różnych dyskursów oddziałuje na kształt życia społecznego ${ }^{12}$. Dla krytycznej analizy dyskursu ważne jest dostrzeżenie związku pomiędzy badanym tekstem a jego celami oraz kontekstem społecznym, w którym występują ${ }^{13}$.

Podejmując analizę exposé Tuska i Szydło, autor bada dyskurs pod kątem przestrzegania przez mówców zasady jakości, ilości, istotności i sposobu, sta-

12 Por. M. Lisowska-Magdziarz, Analiza tekstu $w$ dyskursie medialnym. Przewodnik dla studentów, Wydawnictwo UJ, Kraków 2006, s. 23.

13 Por. tamże, s. 24. 
nowiących część integralną teorii Grice'a ${ }^{14}$. Ewentualna obecność implikatur konwersacyjnych w przemówieniach programowych ujawni intencje mówców. Nieobojętny dla krytycznej analizy dyskursu jest kontekst wygłoszonych przemówień oraz społeczna rola przemawiającego. W analizie autor będzie starał się uniknąć błędu internalizacji, tzn. przypisywania Tuskowi lub Szydło własnych pojęć, przekonań, założeń, sposobu opisu czy kategoryzowania świata ${ }^{15}$.

Materiał badawczy stanowią stenogramy przemówień programowych premiera Donalda Tuska z 18 listopada 2011 roku oraz premier Beaty Szydło z 18 listopada 2015 roku. Teksty exposé dostępne są na oficjalnej stronie internetowej Kancelarii Prezesa Rady Ministrów ${ }^{16}$.

Wybór tych właśnie dyskursów politycznych wynika z następujących przyczyn: po pierwsze, są szczególnie ważne, ponieważ rozpoczynają działania rządów ukonstytuowanych w następstwie wyborów parlamentarnych: w przypadku exposé z 2011 roku ma miejsce kontynuacja rządów koalicji PO-PSL, zaś exposé z 2015 roku zapoczątkowuje samodzielne rządy PiS, po okresie ośmioletniego bycia $\mathrm{w}$ opozycji parlamentarnej. Po drugie, przemówienia programowe reprezentują dwie różne wizje sprawowania władzy, dwóch różnych pryncypiów politycznych, społecznych, gospodarczych, interesujące zatem będzie zweryfikowanie, czy różnice polityczne wpływają na strategie komunikacyjne polityków (to zostanie zbadane w odniesieniu do tzw. zasady współpracy oraz teorii implikatur). Po trzecie, Tusk oraz Szydło reprezentują liczące się na scenie politycznej Rzeczypospolitej ugrupowania partyjne, które nie są postrzegane jako partie populistyczne, ale jako ugrupowania z racjonalnym programem politycznym. Po czwarte, przemówienia programowe dotyczą tego samego państwa (Rzeczypospolitej), o ustroju demokratycznym, w niezbyt długim odstępie czasu.

\section{Krytyczna analiza dyskursu exposé Donalda Tuska i Beaty Szydło}

Reguła jakości zakłada niemówienie świadomie nieprawdy ani rzeczy, na które nie ma dowodu ${ }^{17}$. Analiza przemówień programowych Tuska i Szydło ujawnia, że teksty te nie zawierają momentów, w których jednoznacznie nadawcy

\footnotetext{
14 Por. tamże, s. 80.

15 Por. tamże, s. 26.

${ }^{16}$ https://www.premier.gov.pl [dostęp: 1.08.2016]. Pierwsze, wcześniejsze z analizowanych, znajduje się na stronie: https://www.premier.gov.pl/realizacja-planow/expose-premiera-donalda-tuska-stenogram.htm [dostęp: 1.08.2016], zaś drugie, późniejsze, na stronie: https:/www.premier. gov.pl/stenogram-expose-premier-beaty-szydlo-0.html [dostęp: 1.08.2016].

${ }^{17}$ Por. M.J. Eppler, Managing Information Quality. Increasing the Value of Information in Knowledge-intensive Products and Processes, Springer, Berlin 2003, p. 88; E. Ifantidou, Evidentials and Relevance, John Benjamins, Amsterdam/Filadelfia 2001, p. 67; M. Lisowska-Magdziarz, dz. cyt., s. 80.
} 
komunikatu ujawnialiby chęć świadomego wprowadzania w błąd swoich adresatów. Analizowane exposé są przemówieniami programowymi osób desygnowanych na urząd Prezesa Rady Ministrów przed udzieleniem im wotum zaufania przez parlament. $Z$ natury swojej w ustrojach demokratycznych ten rodzaj dyskursu politycznego ma charakter ogólny, wskazuje jedynie orientacyjne kierunki działań rządu, założone cele do zrealizowania, wartości, które będą wytyczały prace rządu, a także pozytywne sygnały zapraszające do wspólnego realizowania programu. Nie jest to zatem, wydaje się, stosowne miejsce na świadome mówienie nieprawdy, jeśli w ogóle można mówić o takiej przestrzeni publicznej, w której nierespektowanie zasady prawdy przekazu byłoby pewnego rodzaju ,standardem" do zaakceptowania.

Cele działań Rady Ministrów zaprezentowane w exposé wykazują często bardzo wysoki stopień optymizmu w realizacji założonych wcześniej celów. Ta swego rodzaju lista nowych kierunków polityki rządu może skłaniać do postawienia pytania o realność ich wdrożenia. Jeśli dany punkt programu rządu jest w zasadzie niemożliwy do urzeczywistnienia, to należy go uznać za program utopijny i łamiący regułę jakości Grice’a. Takie momenty w przemówieniach programowych Tuska i Szydło można odnaleźć, np.:

- Donald Tusk zapowiada zniesienie podziału w społeczeństwie na bezzasadnie uprzywilejowanych oraz najsłabszych i wyraża nadzieję, że wszyscy obywatele zgodzą się na działania rządu mające zaprowadzić sprawiedliwość społeczną:

Zakładam, że trudna, ale akceptacja, zrozumienie bez entuzjazmu dla wielu tych działań będzie możliwe tylko wtedy, kiedy uczciwie powiemy, że nie będzie świętych krów, że wszyscy, którzy dzisiaj korzystają z przywilejów mniej czy bardziej uzasadnionych, z wyłączeń, że wszyscy, bez rewolucyjnych i drastycznych metod zgodzą się na to samo ograniczenie na rzecz tych najsłabszych, na rzecz tych, którzy płacą też największe ciężary ${ }^{18}$.

Tusk łamie zasadę jakości, ponieważ zastosowanie przez niego wielkiego kwantyfikatora (,wszyscy”) wskazywałoby zgodę wszystkich bez wyjątku obywateli na działania rządu. Nadawca takiego komunikatu ma świadomość nierealności jego spełnienia.

- Beata Szydło z kolei obiecuje podjęcie się rozwiązania wszystkich problemów natury gospodarczej, społecznej i stanu państwa:

Musimy podjąć wyzwania przyszłości. A te są jasne. Musimy wyrwać się z pułapki średniego rozwoju. To znaczy przyspieszyć tempo wzrostu. Podjąć rozwiązania

${ }^{18}$ Exposé premiera Donalda Tuska - stenogram, 18.11.2011, https://www.premier.gov.pl/realizacja-planow/expose-premiera-donalda-tuska-stenogram.html [dostęp: 1.08.2016]. 
wszystkich problemów, przed którymi stanęła Polska w sferze gospodarczej, spraw społecznych i stanu państwa. Jeśli chodzi o jego kondycję wewnętrzną i międzynarodową ${ }^{19}$.

Podobnie można ocenić te momenty dyskursu politycznego, które wyrażają przekonanie o współpracy wszystkich parlamentarzystów na rzecz państwa i na rzecz wspólnego realizowania celów - to wpisuje się raczej w kategorię świadomego nadania exposé pewnej formy retorycznej deklaracji, np. zapewnienia Tuska i Szydło o jakimkolwiek braku ambicji politycznych w wypełnianiu przez nich urzędu premiera:

[Donald Tusk] Chcę podziękować bardzo Polskiemu Stronnictwu Ludowemu za to, że tworzymy po raz kolejny bezpieczną dla Polski koalicję. Budujemy dzisiaj w Polsce wielkie, bezpieczne dla Polaków polityczne centrum, nie dla politycznych ambicji czy aspiracji ${ }^{20}$.

[Beata Szydło] Rząd Prawa i Sprawiedliwości jest gotowy do współdziałania opartego na zgodzie i porozumieniu. Dlatego dzisiaj proszę całą Wysoką Izbę, bez wyjątku, wszystkich Państwa o taką merytoryczną i zgodną współpracę. Nie dla nas. Nie dla naszych ambicji politycznych. Nie dla naszych karier, ale dla Polaków ${ }^{21}$.

Reguła istotności zakłada, że nadawca przekazu mówi na temat i wypowiada sądy istotne z punktu widzenia tematu komunikacji ${ }^{22}$.

Zarówno exposé premiera Tuska, jak i premier Szydło cechuje jasność we wskazaniu najważniejszych tematów, którymi chce zająć się rząd. Oboje liderzy polityczni wyszczególniają najistotniejsze punkty przyszłej działalności Rady Ministrów. Premier rządu PO-PSL podejmuje w swoim przemówieniu programowym następujące kwestie: wzrost PKB w Polsce, debata o przyszłości Unii Europejskiej, budżet na rok 2012, wyjście Polski z procedury nadmiernego deficytu, dążenie do obniżenia długu publicznego, nowe zasady w przyznawaniu ulgi w podatkach, becikowego i w uldze prorodzinnej, usprawnienie pracy sądów, zmiany w systemie emerytalnym, nowe zasady w systemie ubezpieczeń społecznych rolników, utrzymanie wskaźnika natowskiego w odniesieniu do armii i innych służb państwowych ${ }^{23}$. Z kolei premier rządu PiS wskazuje następujące wyzwania stojące przed nowym rządem:

${ }^{19}$ Exposé premier Beaty Szydło - stenogram, 18.11.2015, https://www.premier.gov.pl/stenogram-expose-premier-beaty-szydlo-0.html [dostęp: 1.08.2016].

${ }^{20}$ Exposé premiera Donalda Tuska - stenogram, dz. cyt.

${ }^{21}$ Exposé premier Beaty Szydto - stenogram, dz. cyt.

22 Por. M.J. Eppler, dz. cyt., s. 88; M. Lisowska-Magdziarz, dz. cyt., s. 80.

23 Por. Exposé premiera Donalda Tuska-stenogram, dz. cyt. 
Po pierwsze, pięćset złotych na dziecko, począwszy od drugiego, a w rodzinach o mniejszych dochodach od pierwszego dziecka. [...] Po drugie, obniżenie wieku emerytalnego do sześćdziesięciu lat dla kobiet i sześćdziesięciu pięciu lat dla mężczyzn. Po trzecie, podniesienie do ośmiu tysięcy złotych kwoty wolnej od podatku. Po czwarte, bezpłatne leki od siedemdziesiątego piątego roku życia. Po piąte, podwyższenie minimalnej stawki godzinowej do dwunastu złotych ${ }^{24}$.

Beata Szydło w dalszej części dyskursu wskazuje również inne, bardziej szczegółowe kierunki polityki jej rządu, m.in. obniżenie podatku CIT dla małych firm, powołanie Narodowego Forum Przedsiębiorców przy Prezesie Rady Ministrów, znaczne zwiększenie udziału inwestycji w PKB ${ }^{25}$.

Reguła ilości zakłada, że w procesie komunikowania nadawca udziela odpowiedniej ilości informacji, koniecznej na danym etapie prowadzonego dyskursu (tzn. ani za dużo, ani za mało informacji) ${ }^{26}$.

Wymienione przy okazji omówienia reguły istotności najważniejsze wyzwania stojące przed rządami PO-PSL oraz PiS, które można uznać jako podstawowe kwestie exposé, spełniają również regułę ilości Grice’a. W procesie komunikowania politycznego, zarówno Tusk, jak i Szydło podają zasadniczo odpowiednią ilość informacji, tłumacząc istotę kwestii poruszanych w dyskursie. Podane informacje zapewniają odbiorcom właściwą orientację w temacie, nie są one jednak nadmiernie szczegółowe, np. premier Szydło, wypowiadając się na temat polityki prorodzinnej i pronatalistycznej, wymienia trzy podstawowe kierunki działań na rzecz rodziny, są nimi: przełamanie zapaści demograficznej, podjęcie walki z biedą oraz odbudowa w Polsce wiary w demokrację ${ }^{27}$. Tusk, mówiąc o finansach publicznych, przytacza najważniejsze dane z gospodarki na temat deficytu sektora finansów publicznych, długu publicznego i o prognozach mających doprowadzić do obniżenia deficytu na koniec kadencji jego rządu do mniej więcej 1 proc. PKB. Nie dostrzega się, by oprócz przekazania podstawowych danych gospodarczych, podejmował szczegółową interpretację stanu gospodarki Polski. Podobnie lider PO wypowiada się w 2011 roku na temat zwiększonej daniny pobieranej od wydobywanych bogactw naturalnych, głównie miedzi i srebra. Wyjaśnienia są przekazane w odpowiedniej objętości tekstu, nie stanowią wywodu ani zbyt obszernego, ani zbyt krótkiego:

Chcemy, po pierwsze, wyraźnie zwiększyć i unowocześnić daninę, którą w tej chwili pobieramy w niewystarczającym stopniu od wydobywanych bogactw naturalnych, przede wszystkim miedź i srebro, warto pamiętać, że według źródeł międzynarodo-

\footnotetext{
${ }^{24}$ Exposé premier Beaty Szydło - stenogram, dz. cyt.

${ }^{25}$ Por. tamże.

${ }^{26}$ Por. M.J. Eppler, dz. cyt., s. 87-88; M. Lisowska-Magdziarz, dz. cyt., s. 80 .

${ }^{27}$ Por. Exposé premier Beaty Szydło - stenogram, dz. cyt.
} 
wych złoża tych dwóch, bardzo ważnych dla Polski bogactw, są jednymi z największych na świecie i największymi w Europie ${ }^{28}$.

Reguła sposobu nakazuje „mówić możliwie krótko, raczej prosto, w sposób uporządkowany oraz unikając niejasności i wieloznaczności”29.

Naruszenie maksymy sposobu dostrzegalne jest w preambule exposé Tuska. Premier rządu PO-PSL w słowie podziękowania skierowanym do Polaków wyraża swoje uznanie i podziękowanie w sposób następujący:

Chcę podziękować wszystkim w Polsce, wszystkim obywatelom, bez wyjątku, niezależnie od tego, czy zaufali w akcie wyborczym tej ekipie, której przyjdzie prowadzić prace państwowej administracji przez następną kadencję, czy też tym, którzy mieli inny pogląd $\mathrm{w}$ tej kwestii, bo to podziękowanie, to nie tylko gorące słowa za sam akt wyboru. To przede wszystkim najwyższe uznanie dla polskiego narodu, dla Polek i Polaków za ten wielki wysiłek, wielką odwagę, spokój i determinację, jaką wykazali w ostatnich czterech latach ${ }^{30}$.

Tusk nie mówi krótko i prosto, kiedy wypowiada frazę „podziękować wszystkim obywatelom”, to oczywiście „podziękować bez wyjątku”, czego nie trzeba specjalnie doprecyzowywać w dyskursie. Niejasne i wieloznaczne są słowa „wielki wysiłek, spokój i determinacja” w odniesieniu do postawy Polaków od 2007 do 2011 roku. Czy premier rządu PO-PSL miał na myśli brak manifestacji ulicznych, brak strajków, a może brak zainteresowania się Polaków sytuacją polityczną, a jedynie koncentrowanie uwagi obywateli na własnych sprawach? Podobnie dalsze zdania Tuska na temat kryzysu i trudności czasów współczesnych są niejednoznaczne w interpretacji: „Nie było to łatwe, bo czasy, w jakich przyszło nam żyć, okazały się bardziej skomplikowane, bardziej nieprzewidywalne niż ktokolwiek mógł pomyśleć kilka lat temu" "31. Czy przyczyną złożoności czasu był kryzys finansowy czy może katastrofa samolotu Tu-154 pod Smoleńskiem 10 kwietnia 2010 roku, a może nasilające się procesy emigracyjne młodych Polaków i zapaść demograficzna?

Także w preambule exposé premier rządu PiS można dostrzec łamanie maksymy sposobu: „Polska polityka musi być inna. Pokora, praca, umiar, roztropność w działaniu i odpowiedzialność. A przede wszystkim słuchanie obywateli. To są zasady, którymi będziemy się kierować. Koniec z arogancją władzy i koniec z pychą"32. Wypowiedź tę można odczy tać jako wieloznaczną: czy arogancja władzy

\footnotetext{
${ }^{28}$ Exposé premiera Donalda Tuska - stenogram, dz. cyt.

${ }^{29}$ M. Lisowska-Magdziarz, dz. cyt., s. 80; por. także M.J. Eppler, dz. cyt., s. 88.

${ }^{30}$ Exposé premiera Donalda Tuska - stenogram, dz. cyt.

${ }^{31}$ Tamże.

${ }^{32}$ Exposé premier Beaty Szydto - stenogram, dz. cyt.
} 
i pycha były w opinii Beaty Szydło cechą rządów PO-PSL w latach 2007-2015, czy może cechy te odnosiły się do niektórych tylko parlamentarzystów, niezależnie od przynależności partyjnej, a zamieszanych w różnego rodzaju afery korupcyjne? To nie jest do końca jasne, choć odbiorca komunikatu takie właśnie wnioski może przyjąć jako racjonalne. Wydaje się, że Tusk i Szydło świadomie unikają jednoznaczności i jasności przekazu, aby zastosować implikatury konwersacyjne do przekazania treści swoim odbiorcom nie wprost, ale w sposób aluzyjny, możliwy do odszyfrowania, zgodnie $\mathrm{z}$ wyznawanymi poglądami politycznymi czy też, w szerszym kontekście, ze światopoglądem.

Przywołajmy inne fragmenty z exposé Tuska i Szydło, które łamią maksymę sposobu i jednocześnie dają nadawcom możliwość wykorzystania implikatury konwersacyjnej.

Dyskurs Donalda Tuska w kwestii bezpieczeństwa i dobrobytu, które jego rząd chce zapewnić wszystkim Polakom, jest zawiły i odległy od sposobu, który można by zdefiniować jako prosty:

Ja dzisiaj chcę otwarcie, uczciwie skoncentrować się na tych trudnych wyzwaniach, od których zależy dzisiaj los nie tylko Polski, ale w każdym kraju europejskim, politycy i obywatele żyją w tym przeświadczeniu, że właśnie teraz rozstrzyga się przyszłość ich krajów i przyszłość Europy, przede wszystkim przyszłość zwykłych ludzi, bo nikt z nas nie ma wątpliwości, że wszystkie starania naszego rządu, całej Wysokiej Izby, tak jak w przeszłości, tak i w przyszłości muszą być nakierowane przede wszystkim na bezpieczeństwo i dobrobyt każdego człowieka z osobna, narodu, państwa, ale każdego człowieka z osobna, każdego Polaka z osobna w szczególności³ ${ }^{33}$.

Brak jasności tego, co Tusk rozumie przez wyrażenia „zwykli ludzie” (czy jest to synonim użytej nieco później frazy „każdy Polak z osobna w szczególności”?) oraz „bezpieczeństwo i dobrobyt każdego człowieka” wskazuje na zastosowanie przez lidera PO implikatury konwersacyjnej, która może wyrażać pragnienie postrzegania siebie jako „ojca narodu polskiego” czy też jedynego lidera politycznego, zdolnego zagwarantować sukces społeczny, gospodarczy, polityczny, kulturalny Polski. Wydaje się, że Tusk stosuje popularne w retoryce politycznej wyrażenie „zwykli ludzie”, a jednocześnie indywidualizuje swoich adresatów, by uwiarygodnić autentyczność własnego dyskursu przed opinią publiczną.

Z wypowiedzi Donalda Tuska nie wynika dokładnie, do jakiego okresu historii nawiązuje polityk PO, kiedy podejmuje temat wzrostu PKB w Polsce: „[...] chcę podkreślić, że ten wynik pokazujący, że jak nigdy dotąd w historii naprawdę skutecznie goniliśmy najbardziej rozwinięte państwa Europy i świa-

\footnotetext{
${ }^{33}$ Exposé premiera Donalda Tuska - stenogram, dz. cyt.
} 
ta [...]"34. Wyrażenie ,jak nigdy dotąd w historii” jest wieloznaczne. Zastosowana implikatura może służyć Tuskowi do polepszenia własnego wizerunku w oczach społeczeństwa.

- Budowa wspólnej Europy wymaga zdaniem Tuska być może „głębokiej korekty wizji wspólnej Europy” oraz ,inteligentnego, odważnego i elastycznego działania"35. Są to wyrażenia niejasne, choć zawierają dodatkową informację na temat ukrytych intencji rządów PO-PSL - np. zastosowana implikatura może być interpretowana jako wzrost podatków, zmiana ilości wydatków przeznaczonych na szkolnictwo czy uzbrojenie lub w inny sposób.

- Debata na temat budowy silnej Polski w Unii Europejskiej, w opinii Tuska, „będzie debatą, która zaangażuje wszystkie kluby, być może także środowiska poza parlamentem, poza światem polityki”36. Jest to wizja dość utopijna i niejasna. Nie wiadomo dokładnie, w jaki sposób Tusk interpretuje użyte słowo „zaangażuje” oraz które dokładnie środowiska ma na myśli. Celem zastosowanej tego rodzaju implikatury wydaje się budowanie przez polityka PO wizerunku premiera dialogu w ważnych sprawach Polski.

- Tusk nie wyraża się wystarczająco jasno w kwestii ewentualnych możliwych instrumentów umożliwiających zwiększenie dyscypliny finansów publicznych:

Mówię o tym z bólem, ale kiedy mamy do wyboru kilka narzędzi, które umożliwią zwiększenie dyscypliny finansów publicznych, to uznajemy, że w czasie kryzysu, który może także do Polski dotrzeć, musimy przede wszystkim zadbać o bezpieczeństwo obywateli, finansowe, elementarne bezpieczeństwo obywateli ${ }^{37}$.

Nie za bardzo wiadomo, jak interpretować wyrażenie „kilka narzędzi”, nie jest jasne dla odbiorcy, jakie możliwe rozwiązania problemu finansów publicznych ówczesny lider PO ma na myśli. Tusk stosuje ten rodzaj implikatury, by pokazać opinii publicznej, że wybrał opcję najkorzystniejszą dla społeczeństwa.

- Podobnie niejasna i wieloznaczna argumentacja Tuska w kwestii przedłużenia wieku emerytalnego może rodzić szereg pytań dotyczących praktycznych konsekwencji reformy: ,[...] nie utrzymamy tego systemu emerytalnego, nie utrzymamy Polski na powierzchni wody w czasie tego sztormu, jeśli nie zdecydujemy się na ten bardzo twardy krok" ${ }^{\prime 38}$. Tusk, podobnie jak w poprzednim przykładzie, stosując implikaturę, wskazuje, że rząd wybiera najlepsze rozwiązanie dla społeczeństwa, zakładające jednak wyrzeczenia, których bliżej nie precyzuje.

\footnotetext{
34 Tamże.

35 Tamże.

36 Tamże.

37 Tamże.

38 Tamże.
} 
- Słowa premiera rządu PO-PSL, nawiązujące do kwestii światopoglądowych i religijnych, są również niejasne i wieloznaczne:

A narodowa wspólnota potrzebuje także wspólnych znaków, wspólnych symboli, wspólnej tradycji, poszanowania dla niej, nie musimy wyznawać tego samego systemu wartości w stu procentach, nikt nikomu tego nie nakaże, ale nie powinniśmy także ani na siłę nikogo chrystianizować, ale też na pewno nie musimy też nikogo na siłę laicyzować. Niech żaden polityk nie próbuje też bezcześcić tak ważnych, świętych znaków i symboli dla większości Polaków. Krzyż nie powinien służyć do łomotania przeciwnika politycznego niczym maczugą, ale krzyż też nie powinien być powodem do kolejnej wojny politycznej, tu w Sejmie czy poza tym budynkiem ${ }^{39}$.

Wydaje się, że jest to zabieg celowy Tuska, by zdobywać poparcie społeczne dla działań rządu ze strony różnych środowisk ideowych.

- Wieloznaczny w interpretacji jest fragment exposé Beaty Szydło na temat poziomu zaufania do polskich sądów:

Polacy mają wyjątkowo niski poziom zaufania do sądów. [...] Ale drodzy Państwo, szczególnie wy, którzy w tej chwili tak ożywiliście się, siedząc na Sali, zastanówcie się, czy nie jest wstydem dla polskiego państwa, dla nas wszystkich, że dzisiaj w Polsce zabiera się rodzicom dzieci tylko dlatego, że rodzina ma niskie dochody. Czy to nie jest nasz wstyd? Wy tego nie chcecie dostrzec? My to dostrzegliśmy i zmienimy to. Przeprowadzimy zmiany tej ustawy ${ }^{40}$.

Wykorzystana implikatura ma na celu ukazać zamiar nowego rządu PiS uzdrowienia, jak można wywnioskować, niesprawiedliwego systemu prawa poprzez wprowadzenie nowych ustaw.

- Końcowa część przemówienia pani premier obliguje do postawienia pytania, co Beata Szydło miała na myśli, mówiąc, że „,nie można nazywać solidarnością prób swego rodzaju eksportu problemów, jakie stworzyły sobie pewne państwa bez jakiegokolwiek udziału innych, które mają być nimi obciążone" W opinii wielu komentatorów życia politycznego premier rządu PiS skrytykowała politykę Niemiec i kanclerz Angeli Merkel dotyczącą niekontrolowanego napływu uchodźców z Bliskiego Wschodu oraz zasygnalizowała nowy kierunek polityki Polski w tej kwestii ${ }^{42}$.

39 Tamże.

${ }^{40}$ Exposé premier Beaty Szydło - stenogram, dz. cyt.

41 Tamże.

42 Por. np. A. Dubiel, T. Rowiński, Imigracja kwestia ważna czy nie? Temat imigracji w mediach w dniu exposé Beaty Szydło, Narodowy Ośrodek Analiz Medialnych, http://christianitas. org/news/imigracja-kwestia-wazna-czy-nie-temat-imigracji-w-mediach-w-dniu-expose-beaty- 
W tych samych przemówieniach programowych Tuska i Szydło można odnaleźć momenty dyskursu, które spełniają regułę sposobu Grice’a - przekaz jest czytelny, jednoznaczny, pozbawiony wątpliwości. W ogólnej ocenie porównywalna jest jednak ilość przykładów potwierdzających respektowanie maksymy sposobu przez polityków w poddanych analizie dyskursach. Przywołajmy kilka przykładów:

- Tusk jednoznacznie wyjaśnia kryteria otrzymania ulgi prorodzinnej:

Dlatego w rodzinach, w których dochód przekracza 85 tysięcy rocznie, mówimy w związku z tym o tym drugim progu podatkowym, przysługiwać świadczenie, ta ulga prorodzinna będzie w sytuacji, kiedy będzie co najmniej dwójka dzieci, mówiąc ludzkim językiem, zamożni Polacy, którzy mają tylko jedno dziecko, tej ulgi nie będą otrzymywali ${ }^{43}$.

- Premier rządu PO-PSL unika niejasności i wieloznaczności w wyjaśnieniu nowych zasad dla tzw. umów autorskich oraz w omówieniu przyczyn i konsekwencji likwidacji ulgi na internet:

Analogiczną zasadę zaproponujemy, ograniczając przywilej podatkowy dla tak zwanych umów autorskich. Odpisanie 50 proc. kosztów uzyskania przychodu będzie możliwe wtedy, kiedy ten przychód, z tytułu tej działalności, nie przekracza 85 tysięcy złotych rocznie. Powyżej tego progu, od kwoty powyżej tego progu, korzystający $\mathrm{z}$ tych uprawnień będą płacili normalny, tak jak każdy inny obywatel, podatek. [...] mając świadomość, że usługi internetowe relatywnie tanieją, likwidację ulgi na internet. To powinno przynieść w ciągu tych czterech lat oszczędności około, trochę ponad półtora miliarda złotych ${ }^{44}$.

- Premier Tusk informuje ponadto opinię publiczną o stworzeniu nowych przepisów uniemożliwiających omijanie tzw. podatku Belki, o praktycznych konsekwencjach usprawnienia pracy sądów oraz o nowych zasadach dotyczących płacenia składki zdrowotnej przez rolników. Czyni to w sposób jasny i zrozumiały:

Są już przygotowane konkretne przepisy, to kolejny punkt, które zamkną możliwość omijania podatku od dochodów kapitałowych przy lokatach bankowych, mówimy o tak zwanych dziennych lokatach przy podatku Belki [...]. Chcemy, i to będzie główne zadanie nowego ministra sprawiedliwości, czy jedno z głównych zadań, usprawnić pracę sądów, co powinno w tej kadencji przynieść efekt skrócenia

szydlo/ [dostęp: 1.08.2016]; P. Reszka, Dwa exposé. I świetny debiut Petru, https://www.tygodnikpowszechny.pl/to-byly-dwa-expose-i-swietny-debiut-petru-31273 [dostęp: 1.08.2016].

${ }^{43}$ Exposé premiera Donalda Tuska - stenogram, dz. cyt.

${ }^{44}$ Tamże. 
średniego czasu postępowania o jedną trzecią. [...] Tak, jak do tej pory państwo dalej ma zamiar opłacać, jeśli nasza intencja zostanie przyjęta, składkę dla rolników o najniższych dochodach, czyli w gospodarstwach do 6 hektarów. Rolnicy na gospodarstwach od 6 do 15 hektarów będą płacili połowę składki płaconej dziś przez osoby mające działalność gospodarczą poza rolnictwem, a powyżej 15 hektarów całą składkę. Mówimy o tej składce, o tej części składki, która jest poza podatkiem dochodowym, a więc to, co jest, to, co wynosi 36 złotych dla tych zamożniejszych rolników i co będzie wynosiło 18 złotych dla tych od 6 do 15 hektarów ${ }^{45}$.

- Również pozbawione dwuznaczności są słowa lidera koalicji PO-PSL na temat skali deficytu funduszu ubezpieczeń społecznych oraz propozycji sposobu waloryzacji w 2012 roku rent i emerytur:

Ta zmiana pozwoli nam zaledwie ograniczyć deficyt funduszu ubezpieczeń społecznych, mniej więcej o 13 miliardów złotych rocznie, podkreślam jeszcze raz skala dzisiaj przekracza 20 miliardów. [...] biorąc pod uwagę narastający rozziew między wysokimi emeryturami, a tymi najniższymi, proponujemy, aby każdego roku podejmować decyzje, tu w Wysokiej Izbie i zaproponujemy to na rok 2012, aby przez jakiś czas waloryzacja rent i emerytur miała charakter kwotowy, a nie procentowy ${ }^{46}$.

- Perspektywy w kwestii PKB oraz wzrost wynagrodzeń dla policji i wojska Tusk przedstawia jednoznacznie:

Jeśli chodzi o rok 2020 to w tej perspektywie, dzięki wprowadzeniu tej zmiany ten dług w relacji do PKB spadnie do 44 proc., w roku 2030 do 40 proc., a do 2040 do 35 proc. PKB. [...] I dlatego równocześnie zaproponujemy na początek w policji i w wojsku podwyżkę, po około 300 złotych dla każdego policjanta kwotowo i każdego żołnierza. Chcemy ją przeprowadzić w połowie roku, z dniem 1 lipca. Jeśli warunki na to pozwolą w podobny, może trochę mniejszym, ale chcielibyśmy w podobnym wymiarze powtórzyć ją pod koniec kadencji ${ }^{47}$.

- Szydło w sposób jasny i zwięzły wyjaśnia w swoim exposé, na czym polegać ma aktywizacja polskiego kapitału:

Wszystkie wskazane wyżej projekty wymagają aktywizacji polskiego kapitału. Wykorzystania znanych, ale też łatwych do zidentyfikowania i wykorzystania zasobów. [...] Chodzi o znaczne zwiększenie udziału inwestycji w PKB. Wynosi ono dziś oko-

\footnotetext{
45 Tamże.

46 Tamże.

47 Tamże.
} 
ło $20 \%$, a to jest niewiele. Także w porównaniu z krajami naszej części Europy. Na przykład Czechy, w niektórych latach dochodziły do 30\%. [...] O jakie zasoby chodzi? Po pierwsze środki europejskie. [...] Drugim zasobem są środki banków. [...] Wiąże się to ściśle z kolejnym trzecim zasobem. To jest kilkuset miliardami złotych oszczędności na kontach przedsiębiorstw, które mogą być inwestowane w system zachęt inwestycyjnych. [...] Po czwarte. Znaczne zasoby można znaleźć także poprzez umocnienie banku gospodarki krajowej. [...] Po piąte, wreszcie duże niewykorzystane możliwości mają wielkie przedsiębiorstwa państwowe. Można je wykorzystać poprzez stworzenie funduszu inwestycyjnego ${ }^{48}$.

- Jednoznaczna jest również deklaracja premier rządu PiS dotycząca rozbudowy sieci przedszkoli, istoty dwóch projektów rządu dla polskiej wsi oraz reformy szkolnictwa wyższego i zawodowego:

Dla młodych Polaków zachętą do zakładania rodzin i podejmowania decyzji o rodzicielstwie będzie także kontynuacja rozpoczętej przez naszych poprzedników rozbudowy sieci przedszkoli. Naszym celem jest, by były one bezpłatne. Przynajmniej dla rodzin o niższych i średnich, a także nieco większych niż średnich dochodach. [...] Polska wieś potrzebuje dobrego gospodarza. Tu też w centrum jest słowo wyrównywanie. Wyrównywanie poziomu życia, wyrównywanie szans. Dla polskich rolników mamy przygotowane dwa konkretne projekty, które wprowadzimy w pierwszych stu dniach naszych rządów. Pierwszy dotyczy ubezpieczeń rolniczych. Regulacje, które przygotowaliśmy są bardzo potrzebne. Sami rolnicy mówili o nich nie raz. Drugi projekt dotyczy sprawy, o którą polscy rolnicy zabiegają od dłuższego czasu. Chodzi o ochronę polskiej ziemi. [...] Wielkim wyzwaniem, przed którym stoimy jest też oświata i sprawy szkolnictwa wyższego. Zacznę od tej pierwszej. W kontekście oświaty, a także problemu polskich rodzin należy powiedzieć o wprowadzonym wbrew woli rodziców obowiązku szkolnym dla sześciolatków. Nasz rząd cofnie te zmiany. Polscy rodzice będą mieli prawo wyboru, bo najlepiej znają swoje dzieci. To rodzice będą decydowali, czy ich dziecko pójdzie do szkoły w wieku lat sześciu czy w wieku lat siedmiu. Tę zmianę przeprowadzimy w ciągu pierwszych stu dni naszego rządu. Zmiany obejmą też system kształcenia szkolnego. Stopniowo wrócimy do ośmioletniej szkoły podstawowej i czteroletniego liceum. [...] Trzeba dostosować szkolnictwo zawodowe do potrzeb rynku, do potrzeb gospodarki ${ }^{49}$.

- Trzy priorytety w kwestii bezpieczeństwa, sformułowane w sposób krótki przez Beatę Szydło, odnoszą się do polityki zagranicznej obronnej Polski:

\footnotetext{
${ }^{48}$ Exposé premier Beaty Szydto - stenogram, dz. cyt.

49 Tamże.
} 
W zakresie polityki zagranicznej obronnej i związanej z tym sprawy bezpieczeństwa kraju będziemy się kierować trzema priorytetami, będziemy mieć trzy cele. Po pierwsze bezpieczeństwo rozumiane klasycznie, gdy konflikt zbrojny, choć dziś zamrożony, toczy się u granic naszego kraju. Po drugie bezpieczeństwo gospodarcze. Szczególnie w sferze energetycznej, a także informatycznej. Po trzecie wreszcie uzyskanie właściwego statusu i pozycji państwa na arenie międzynarodowej ${ }^{50}$.

\section{Wnioski}

W analizowanych przemówieniach programowych spełnione są niektóre tylko reguły Grice’a, zarówno w orędziu Tuska, jak i Szydło. Poddane badaniom exposé polityków cechuje dość wysoki stopień ogólności przekazu. To, co łączy dwa analizowane dyskursy, to respektowanie w nich zasad ilości i istotności. To można dostrzec w przedstawianych kwestiach, będących pryncypiami działań rządu.

Przeprowadzona analiza wykazała jedynie częściowe przestrzeganie zasady jakości i sposobu. Wydaje się, że jest to spowodowane kilkoma przyczynami. Po pierwsze, wynika to z charakteru exposé, w którym niezwykle trudno jest wyjaśnić wszystkie szczegóły politycznych zamierzeń. Exposé ma swoje ramy czasowe dyscyplinujące, w konsekwencji zmuszające mówcę do dokonania selekcji komunikatu. Ze szczegółowego omówienia wielu kwestii polityk po prostu musi zrezygnować. Po drugie, mówienie ogólnikowe otwiera furtkę do przekazywania treści na drodze implikatury konwersacyjnej. Wypowiedź nabiera wtedy charakteru aluzyjnego, co może być wygodne dla nadającego komunikat, zwłaszcza gdy towarzyszy mu sympatia ze strony słuchaczy. To bowiem umożliwia wielorakość interpretacji wysyłanego komunikatu. Audytorium przychylnie nastawione do mówcy wyrazi aprobatę dla wygłaszanych przez niego treści, przyjmując jedną z możliwych form interpretacji, tj. tę najbardziej zbliżoną do własnego światopoglądu. Po trzecie, przemówienie programowe cechuje captatio benevolentiae, dlatego też deklarowana wiara premier/premiera we wspólne, wraz z partiami opozycji, zmierzanie do realizacji programu zawartego w exposé, należy zinterpretować w kategorii retoryczno-życzeniowej. Mówca przyjmuje taką strategię, ale ma świadomość niemożności jej spełnienia.

Przy wyważonej ocenie stopnia przestrzegania zasady jakości i sposobu warto zwrócić uwagę na gatunkowe, pragmatyczne i stylistyczne uwarunkowania exposé, a także na kontekst wygłoszenia, by móc lepiej określić respektowanie zasad Grice’a. Zarówno Donald Tusk, jak i Beata Szydło stosują implikatury

\footnotetext{
50 Tamże.
} 
konwersacyjne. Czynią to jednak w różnych celach, które wynikają z okoliczności objęcia urzędu. Premier rządu PO-PSL stosuje taką formę przekazu, ponieważ kontynuuje sprawowanie władzy i chce utwierdzić opinię publiczną w przekonaniu, że Rada Ministrów sprawująca władzę w latach 2007-2011 zapewniła Polakom wzrost gospodarczy, rozwój ekonomiczny kraju, bezpieczeństwo polityczne i społeczne, czyli sprawdziła się, a kolejne wygrane wybory w 2011 roku to mandat społeczny, by kontynuować obrany sposób sprawowania rządów. Inna sytuacja komunikacyjna charakteryzuje exposé Szydło, której rząd obejmuje władzę po ośmiu latach rządzenia Polską przez koalicję PO-PSL, stąd w tle wielu wypowiedzi można odnaleźć słowa krytyki wyrażone w sposób bezpośredni lub aluzyjny pod adresem rządów z lat 2007-2015.

Zrozumienie zastosowania przez polityków czterech głównych reguł Paula Grice'a i teorii implikatur konwersacyjnych stanowi ważne pole badań komunikowania politycznego. Pozwala dostrzec w exposé, jako formie komunikowania politycznego, wymiar dosłowny i wymiar aluzyjny, przez co odbiorca może lepiej zrozumieć intencję nadawcy. Nieobojętny jest także kontekst społeczno-polityczny dyskursu.

\section{Bibliografia}

Dobek-Ostrowska B., Komunikowanie polityczne i publiczne, Wydawnictwo Naukowe PWN, Warszawa 2012.

Dubiel A., Rowiński T., Imigracja kwestia ważna czy nie? Temat imigracji $w$ mediach $w$ dniu exposé Beaty Szydło, Narodowy Ośrodek Analiz Medialnych, http:/christianitas.org/news/ imigracja-kwestia-wazna-czy-nie-temat-imigracji-w-mediach-w-dniu-expose-beaty-szydlo/ [dostęp: 1.08.2016].

Eppler M. J., Managing Information Quality. Increasing the Value of Information in Knowledgeintensive Products and Processes, Springer, Berlin 2003.

Exposé premier Beaty Szydło - stenogram, 18.11.2015, https://www.premier.gov.pl/stenogram-expose-premier-beaty-szydlo-0.html [dostęp: 1.08.2016].

Exposé premiera Donalda Tuska - stenogram, 18.11.2011, https:/www.premier.gov.pl/realizacja-planow/expose-premiera-donalda-tuska-stenogram.html [dostęp: 1.08.2016].

Ifantidou E., Evidentials and Relevance, John Benjamins, Amsterdam/Filadelfia 2001.

Kiklewicz A., Reguty konwersacji H.P. Grice’a: pragmatyka czy semantyka?, „Linguistica Copernicana" 2011, nr 2 (6), s. 25-38, http://www.linguistica.umk.pl/teksty/06_kiklewiczzn. pdf [dostęp: 1.08.2016].

Lisowska-Magdziarz M., Analiza tekstu $w$ dyskursie medialnym. Przewodnik dla studentów, Wydawnictwo UJ, Kraków 2006.

McNair B., An introduction to political communication, Routledge, Londyn-Nowy Jork 2011.

Piontek D., Komunikowanie polityczne i kultura popularna. Tabloidyzacja informacji o polityce, Wydawnictwo Naukowe WNPiD UAM, Poznań 2011.

Pragmatyka [hasło], Stownik języka polskiego PWN, http://sjp.pwn.pl/sjp/pragmatyka;2572266. html [dostęp: 1.08.2016]. 
Reszka P., Dwa exposé. I świetny debiut Petru, https://www.tygodnikpowszechny.pl/to-byly-dwa-expose-i-swietny-debiut-petru-31273 [dostęp: 1.08.2016].

Semantyka [hasło], Stownik języka polskiego PWN, http://sjp.pwn.pl/sjp/semantyka;2575165 [dostęp: 1.08.2016].

Wolton D., La communication politique: construction d'un modèle, „Hermès” (Une revue de l'Institut des sciences de la communication du CNRS) 1989, n. 4, s. 27-42, http://documents. irevues.inist.fr/handle/2042/15353 [dostęp: 01.08.2016], http://documents.irevues.inist.fr/ bitstream/handle/2042/15353/HERMES_1989_4_27.pdf?sequence=1\&isAllowed=y [dostęp: 1.08.2016].

\section{Rafał Leśniczak}

\section{The application of Paul Grice's conversational maxims in political communication - comparative analysis of the inaugural speeches of Donald Tusk and Beata Szydlo}

\section{(Summary)}

The author undertakes a comparative analysis of text of the first speech as Prime Minister by Donald Tusk, on 18 November 2011, as well as by Beata Szydło, on 18 November 2015. The Prime Minister's exposé is a form of political communication. The aim of the research paper is to examine how the communication theory of the British philosopher of language Paul Grice, in particular how the so-called cooperative principle he developed could be used in evaluating the quality of a political statement and the intentions behind it. The author also refers to so-called implicature and the above-mentioned cooperative principle.

Keywords: political communication, conversational implicature, exposé, discourse. 